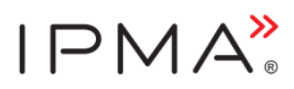

\title{
TECHNOLOGIES ARE NOT ENOUGH TO MAKE A CITY SMART
}

\author{
Reinhard Wagner \\ International Project Management Association
}

\begin{abstract}
During the $5^{\text {th }}$ SENET Conference at Belgrade, hosted by the Serbian Project Management Association (IPMA Serbia) a roundtable was facilitated addressing "SMART Cities - A new perspective for innovative and start-up projects in a digital age". More than 30 people were in attendance and discussed concepts, ideas and questions from a global, regional yet also a local perspective. In my keynote I pointed to the activities of the IPMA Special Interest Group for Smart Cities and a publication, highlighting case stories and perspectives from around the world. Toni Richard Crisolli, coordinator of the "Smart Cities Education Initiative" for Friedrich Naumann Stiftung (FNF) West Balkans explained his work related to "Smart Cities Education", publications and respective events, including but not limited to school labs, a smart city challenge, hackathons and Fuckup events. Since 2016, FNF is collaborating with BEUM Association and ICT-Hub Belgrade, to bring alive the first Smart Cities Challenge Serbia. The Challenge offers young start-ups and smart city developers the opportunity to join Serbia`s first smart city mentorship and exchange programme in the field of urban innovation. Every year, the Challenge helps kick-off several start-ups that generate solutions, products and services that will address and solve urban problems in Serbian cities.
\end{abstract}

Several participants of the roundtable argued that we shall not forget the rural areas and the small cities. Main focus of EU and governmental programmes are the big cities. This may increase the pressure for the rural areas and smaller cities because young people may see their future rather in the big cities than at home. It was also argued during the discussion that smart cities are increasingly depend on smart rural concepts, helping to produce in a sustainable manner what citizens consume. It should be a goal to keep the people where they are, providing jobs close to where people live in order to avoid traffic, reduce pollution and adverse effects. A new IPMA Special Interest Group (SIG) on "Smart Rural" was created to s designed to encourage the understanding and development of Smart Rural approaches and technologies in global projects, to establish a knowledge base on rural innovation and competitiveness, with the participation and exchange among IPMA Member Associations, and finally also to become a global knowledge network for intelligence for the sustainable rural development exchange.

At the end of the round table discussion, the participants were asked to formulate a key message or a key learning which will be summarized in the following bullets:

- Smart Cities means Smart Thinking, digital tools are just supporting the implementation

- Smart Cities are a long-term process, not a goal. However, who is managing this process?

- Education is key for all stakeholders involved in the process of realizing smart cities

- Take small cities, regions, communities and rural areas into account and do not focus only on large cities

- IPMA should be instrumental for realizing smart cities, e.g. through education, standards or best practice sharing

- Realizing smart cities should start from common sense, ingenuity and honesty of the people involved 
- Digitization shouldn't be the only focus, smart city concepts require much more, such as smart concepts and organizing

- Artificial Intelligence (AI) is an emerging technologies that helps us, but does not replace the human intelligence and the need for cooperation and communication

- Forming networks of partners is essential for realizing smart cities, involving universities, public administration, private businesses and start-up with fresh ideas

- Emphasis should be on people, education, education and education, and collaboration of people across all barriers

- Project, programme \& portfolio management (P3M) are key approaches for tackling the challenges cities are faced with

- Learning from each other, across all borders helps to avoid reinventing the wheel and speeding up the realization.

The next event of IPMA addressing Smart Cities will happen May $28^{\text {th }}$ at Incheon / Korea and will be followed by the $31^{\text {st }}$ IPMA World Congress at Merida / Mexico, bringing together experts for Smart Cities and Smart Rural (amongst others). 